\title{
ESTIMATION OF WAVE CHARACTERISTICS IN EAST VIETNAM SEA USING WAM MODEL
}

\author{
Le Dinh Mau*, Nguyen Van Tuan \\ Institute of Oceanography-VAST \\ "Email: ledinhmau.vnio@gmail.com
}

Received: 6-5-2014

\begin{abstract}
WAM (WaveModeling) is a third generation wave model developed by WAMDI Group which describes the evolution of a two-dimensional ocean wave spectrum under the effects of winds, currents, bottom and non-linear wave-wave interactions. The model runs for deep and shallow waters and includes depth and current refraction. This study used the WAM cycle 4.5 with model domain which is covered from $99^{\circ} \mathrm{E}$ to $121^{\circ} \mathrm{E}$ and $0^{\circ} \mathrm{N}$ to $25^{\circ} \mathrm{N}$ with a resolution of $\Delta X=\Delta Y$ $=0.25^{\circ}$. Bathymetry of East Vietnam Sea (EVS) was taken from 'ETOPO5' data set of National Geophysical Data Center, Colorado, USA with resolution of 5' ( $\approx 9 \mathrm{~km})$. Wind velocities were obtained from 6 hourly NCEP/NCAR reanalysis data, USA with resolution of $\Delta X=\Delta Y=0.25^{\circ}$. Study results show that during NE monsoon period, the main wave direction in EVS was NE and vice versa during SW monsoon period. Regions of greatest wave height were in the central and northern part of the EVS. Statistic of computed wave characteristics from 1987 to 2011 shows that wave regime in the offshore region of Nhatrang coast has two main wave directions that are NE with $40.82 \%$ of occurrence, SSW with $20.15 \%$ of occurrence. NE monsoon wave dominated from October to April of the next year, SW monsoon wave dominated from June to August. May and September are transitional periods. Assimilation of wind data with resolution of $\Delta X=\Delta Y=0.25^{0}$ permits the model to be used to simulate the wave field during typhoon activity in EVS.
\end{abstract}

Key words: WAM cycle 4.5, East Vietnam Sea, Wave field, Typhoon, Monsoons.

\section{INTRODUCTION}

The East Vietnam Sea (EVS) is a semienclosed tropical sea located in the southeast of the Asian landmass with a total area of approximately $3,537,000 \mathrm{~km}^{2}$ and average depth of $1,140 \mathrm{~m}$, extending from $99^{0} \mathrm{E}$ to $120^{\circ} \mathrm{E}$ and from $0^{0} \mathrm{~N}$ to $25^{\circ} \mathrm{N}$. It connects to the East China Sea (through Taiwan Strait), the Pacific Ocean (through Luzon Strait), the Sulu Sea, the Java Sea (through Gasperand Karimata Straits) and the Indian Ocean (through the Strait of Malacca). All of these straits are shallow except Luzon Strait, the maximum depth ofwhich is $1,800 \mathrm{~m}$. The EVS is under the influence of monsoon winds and synoptic systems such as fronts and tropical cyclones. From November to March, the weather in the sea is dominated by northeasterly winter monsoon wind and from June to August it is dominated by southwesterly summer monsoon wind.

Determination of wind wave characteristics in offshore area has important role for design of marine-structures, social-economical activities and supply of boundary conditions for nearshore wave computation. Processes of formation, development and dissipation of wave corresponding to the varied condition of wind, current and topography are very complicated matters. SWAMP (1985) [1] 
carried out the comparison various wave models to point out of advantage and shortcoming for each model. Young (1988) developed a model to predict wave during typhoon activity [2]. Londhe and Panchang (2006) carried out a study on One-Day Wave Forecasts Based on Artificial Neural Networks [3]. Mandal and Prabaharan (2003) have an overview of the numerical and neural network Accosts of ocean wave prediction [4]. Mau et al., (2004) used Young model to calculate maximum wave characteristics during typhoon weather in EVS [5]. However, all above mentioned wave models are limited to simulate the progress of wave spectrums especially in case of typhoons, fronts when wind field changes significantly in both directions and speeds. Therefore, the third generation of wave model has to be developed. WAM (acronym for WaveModeling) model is a third generation wave model which solves the wave transport equation explicitly without any presumptions on the shape of the wave spectrum $[6,7]$. It represents the physics of the wave evolution in accordance with our knowledge today for the full set of degrees of freedom of a 2D wave spectrum. The model runs for any given regional or global grid with a prescribed topographic dataset. The grid resolution can be arbitrary in space and time. The wave propagation can be done on a latitudinallongitudinal or a Cartesian grid. The model outputs the significant wave heights, mean wave directions and frequencies, the swell wave heights and mean directions, wind stress fields corresponded with the wave induced stresses and the drag coefficient at each grid point at chosen output times and also the $2 \mathrm{D}$ wave spectrum at chosen grid points and output times. The model runs for deep and shallow water and includes depth refractions and current interactions. The integration can be interrupted and restarted at arbitrary times. The source terms and the propagation are computed with different methods and time steps. The wind time step can be chosen arbitrarily. Subgrid squares can be run in a nested mode. In a course grid run the spectra can be outputted at the boundaries of a sub grid. They can then be interpolated in space and time to the boundary points of the fine sub grid and the model can be rerun on the fine mesh grid. The model has been installed at world-wide institutions and is used for researches and also operational applications. It is also being applied for interpreting and assimilating satellite wave data. Another full-spectral third-generation ocean wind-wave model Wavewatch-III has been implemented for investigating wind-wave characteristics [8]. This model was developed at the Ocean Modeling Branch of the National Centers for Environmental Prediction (NCEP), USA.

To conduct study on wave characteristics in EVS, several researchers from different Institutions applied some kinds of third generation wave models. For example, Chu and Cheng (2008), Mirzaei et al. (2013), Zhou et al. (2014) used WAVEWATCH III [9-11]. Le Dinh Mau (2006) used WAM Cycle 4.0 model with NCEP data [12]. The Vietnam National project KC.09.04/01-05 (2001-2005) "Short time prediction of hydrodynamic processes in EVS", also used WAM Cycle 4.0 model to predict wave fields in EVS. Recently, the Vietnam National project KC.09.19/06-10 (2006-2010) "Study and assessment on the potential of marine energy sources for Vietnam sea", has used SWAN model to estimate wave characteristics in EVS.

\section{MATERIAL AND METHOD}

\section{Materials}

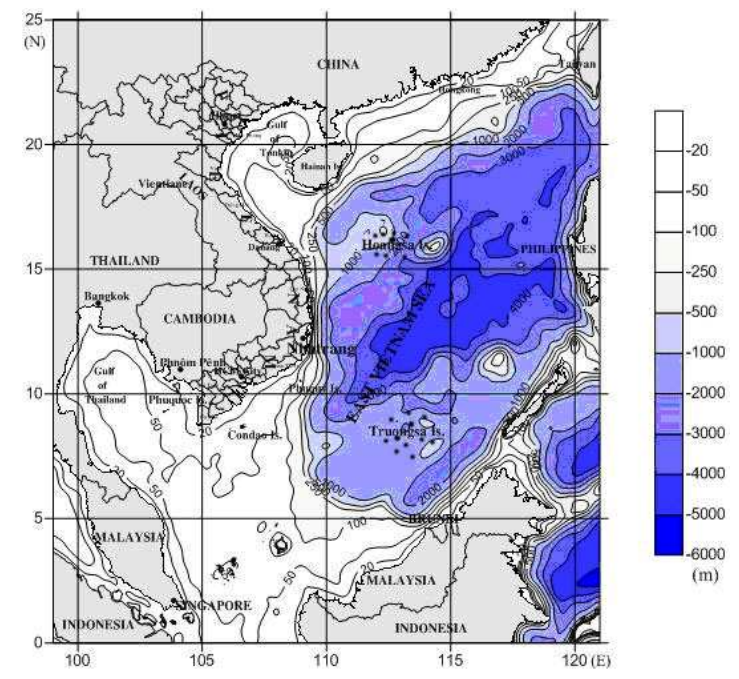

Fig. 1. Topography of East Vietnam Sea

Topography was taken from ETOPO5 with resolution of $5^{\prime}(\approx 9 \mathrm{~km})$. The computed 
domain is covered the area $99^{\circ} \mathrm{E} \div 121^{\circ} \mathrm{E}$ and $0^{0} \mathrm{~N} \div 25^{0} \mathrm{~N}$ with resolution of $0.25^{0} \times 0.25^{0}$ which includes $92 \times 100$ points (fig.1). Measurement of wave characteristics was carried out off Nhatrang coast at water depth of about $15 \mathrm{~m}$ by AWAC wave recorder. Wind data at six hourly intervals from $01 / 7 / 1987$ to $31 / 12 / 2011$ with resolution of $0.25^{0} \times 0.25^{0}$ were downloaded from website: http://apdrc.soest.hawaii.edu/datadoc/ccmp_6h ourly.php which were collected from satellite, Obs.ship, buoys and ECMWF (for 24.5 years with 38,500 data sheets).

\section{Computation methods}

WAM Cycle 4.5 model [7] was used to calculate wave characteristics in the EVS. The evolution of the two-dimensional ocean wave spectrum $\mathrm{F}(\mathrm{f}, \theta, \phi, \lambda, \mathrm{t})$ with respect to frequency $\mathrm{f}$ and direction $\theta$ (measured clockwise relative to true north) as a function of latitude $\phi$ and longitude $\lambda$ on the spherical earth is governed by the transport equation:

$$
\frac{\partial F}{\partial t}+(\cos \varphi)^{-1} \frac{\partial}{\partial \varphi} \stackrel{*}{(\varphi \cos \varphi F)+\frac{\partial}{\partial \lambda}}{ }^{*}(\lambda F)+\frac{\partial}{\partial \theta}{ }^{*}(\theta F)=S
$$

Where $S$ is the net source function describing the change of energy of a propagating wave group and :

$$
\begin{aligned}
& \varphi=\frac{d \varphi}{d t}=v R^{-1} \cos \theta \\
& \lambda=\frac{d \lambda}{d t}=v \sin \theta(R \cos \varphi)^{-1} \\
& \theta=\frac{d \theta}{d t}=v \sin \theta \tan \varphi R^{-1}
\end{aligned}
$$

represent the rates of change of the position and propagation direction of a wave packet traveling along a great circle path. Here, $v=$ $\mathrm{g} / 4 \pi \mathrm{f}$ denotes the group velocity.

The source includes wind input $-S_{\text {in }}$, nonlinear transfer $-\mathrm{S}_{\mathrm{nl}}$, and white capping dissipation source function $-S_{\text {dis }}$ :

$$
\mathrm{S}=\mathrm{S}_{\mathrm{in}}+\mathrm{S}_{\mathrm{nl}}+\mathrm{S}_{\mathrm{dis}}
$$

The model contains 25 frequency bands on a logarithmic scale, with $\Delta f / f=0.1$, spanning a frequency range $f_{\max } / f_{\min }=9.8$ and 12 directional bands $\left(30^{\circ}\right.$ resolutions $)$. The frequency units can be selected arbitrarily. In all hind cast studies the frequency interval extended from 0.042 to $0.41 \mathrm{~Hz}$.

Output data with six hourly intervals from $01 / 7 / 1987$ to $31 / 12 / 2011$ with resolution of $0.25^{0} \times 0.25^{0}$ was carried out.

\section{Verification of modeled results}

Field measurement of wave characteristic to verify the modeled results was carried out off Nhatrang coast $\left(\phi=12^{\circ} 07.125^{\prime} \mathrm{N}, \lambda=\right.$ $109^{\circ} 14.600$ ' $\mathrm{E}, \quad$ depth $\left.\approx 15 \mathrm{~m}\right)$ from $9 \mathrm{~h} 30^{\prime} / 11 / 8 / 2012$ to $16 \mathrm{~h} 00 / 12 / 8 / 2012$ by AWAC wave recorder (fig. 1). Comparison between measured and modeled data is shown in fig. $2 a, b$.

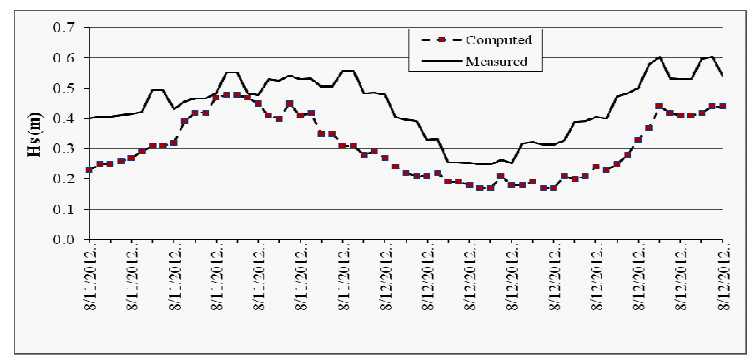

Fig. 2a. Comparison of measured and computed wave heights at Nhatrang station

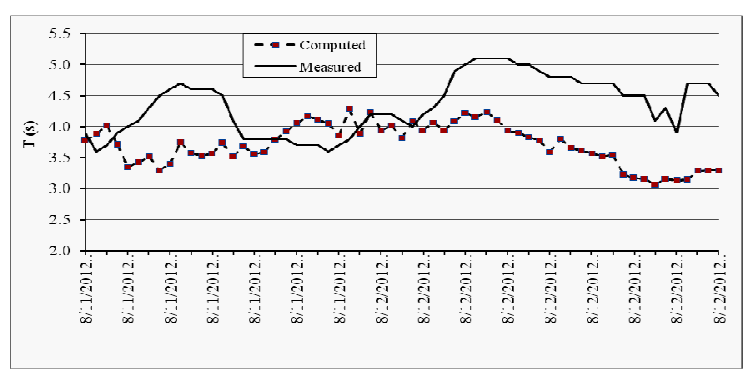

Fig. 2b. Comparison of measured and computed wave periods at Nhatrang station

The period of verification is southwest monsoon. In general the wave heights and wave periods from modeled results are larger than those of measured ones. Relative 
difference between measured and modeled is $13 \%$ for wave heights and $20 \%$ for wave periods. The measured station was located in nearshore and shallow region where conditions affected verified results. Nevertheless, based on the verified results, WAM model can be used to calculate wave characteristics in the EVS.

\section{STUDY RESULTS}

\section{Wave height pattern in EVS during monsoons}

At $0 \mathrm{~h}$ 7/1/2011 wind field over the EVS was strong, mostly of $\mathrm{V} \geq 10 \mathrm{~m} / \mathrm{s}$ especially in the northeast area (Luzon strait) with $\mathrm{V}>$ $16 \mathrm{~m} / \mathrm{s}$ and wind direction was dominated in NE direction. This wind field resulted in wave height field being characteristic of $\mathrm{NE}$ monsoon with relatively stable wave direction from NE. The central region of EVS was prevailed by wind wave with $\mathrm{H}_{\mathrm{s}} \approx 4 \div 5 \mathrm{~m}, \mathrm{~T} \approx$ $8.5 \div 9.0 \mathrm{~s}$. The wave height contour of $\mathrm{H}_{\mathrm{s}} \approx 3 \mathrm{~m}$ was close to central Vietnamese coast and $\mathrm{T} \approx$ $7.5 \div 8.5 \mathrm{~s}$. The gulf of Tonkin has $\mathrm{H}_{\mathrm{s}} \approx 1 \div 3 \mathrm{~m}$, $\mathrm{T} \approx 5 \div 7 \mathrm{~s}$, the gulf of Thailand has $\mathrm{H}_{\mathrm{s}} \approx 1 \div 2 \mathrm{~m}$, $\mathrm{T} \approx 4 \div 6$ s (fig. 3 ).

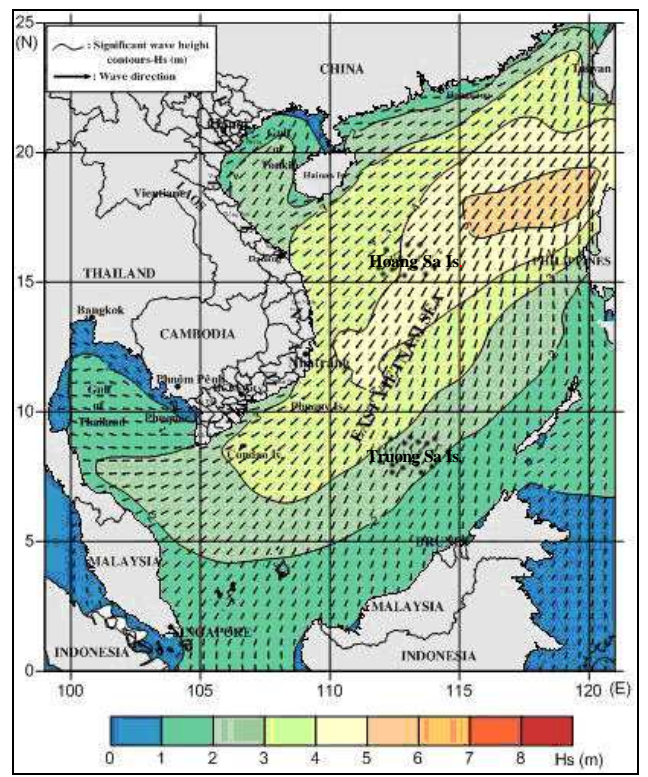

Fig. 3. Wave height pattern in EVS during NE monsoon (at 0h 7/1/2011)

At 0 h 16/7/2011 wind field over EVS was mostly of $\mathrm{V} \geq 6 \mathrm{~m} / \mathrm{s}$, maximum value of 10.8 $\mathrm{m} / \mathrm{s}$ and wind direction was dominated from SE. This wind field resulted in wave height field being characteristic of SW monsoon with relatively stable wave direction from SW. In general EVS was prevailed by wind wave with $\mathrm{H}_{\mathrm{s}} \approx 0.5 \div 1.5 \mathrm{~m}, \mathrm{~T} \approx 4.5 \div 6.0 \mathrm{~s}$. Northeast region of EVS has $\mathrm{H}_{\mathrm{s}} \approx 1.5 \div 2.5 \mathrm{~m}, \mathrm{~T} \approx 6 \mathrm{~s}$ (fig. 4 )

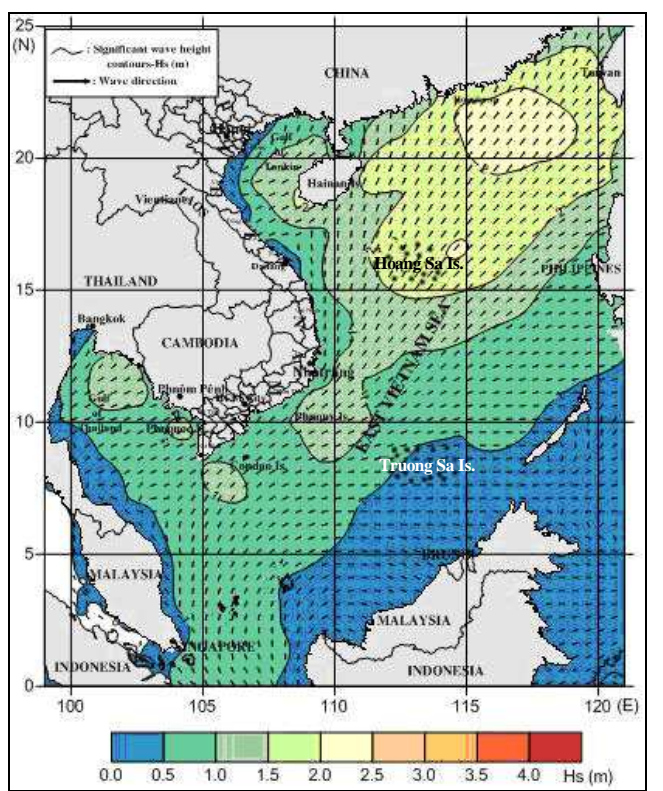

Fig. 4. Wave height pattern in EVS during SW monsoon (at 0h 16/7/2011)

\section{Wave height pattern in EVS during typhoons}

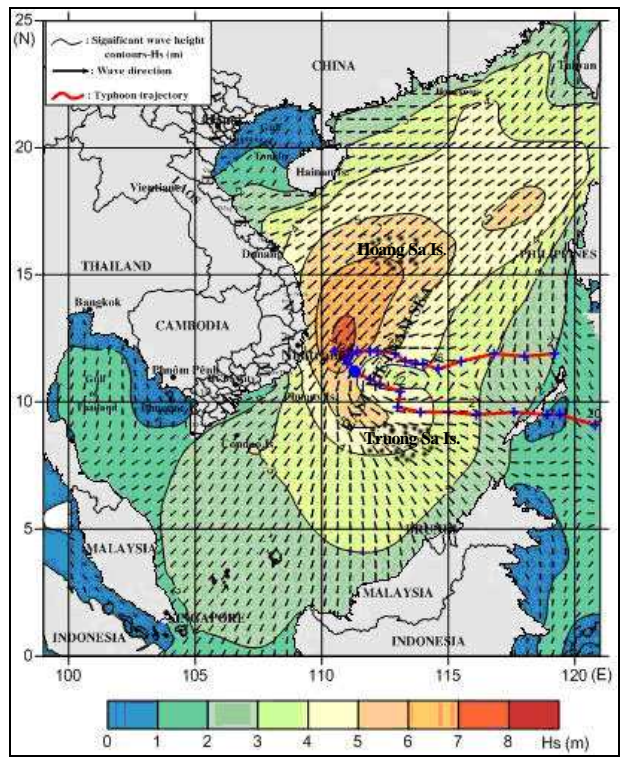

Fig. 5. Wave height pattern induced by typhoon Hagibis (at 18h 22/11/2007) 
Le Dinh Mau, Nguyen Van Tuan

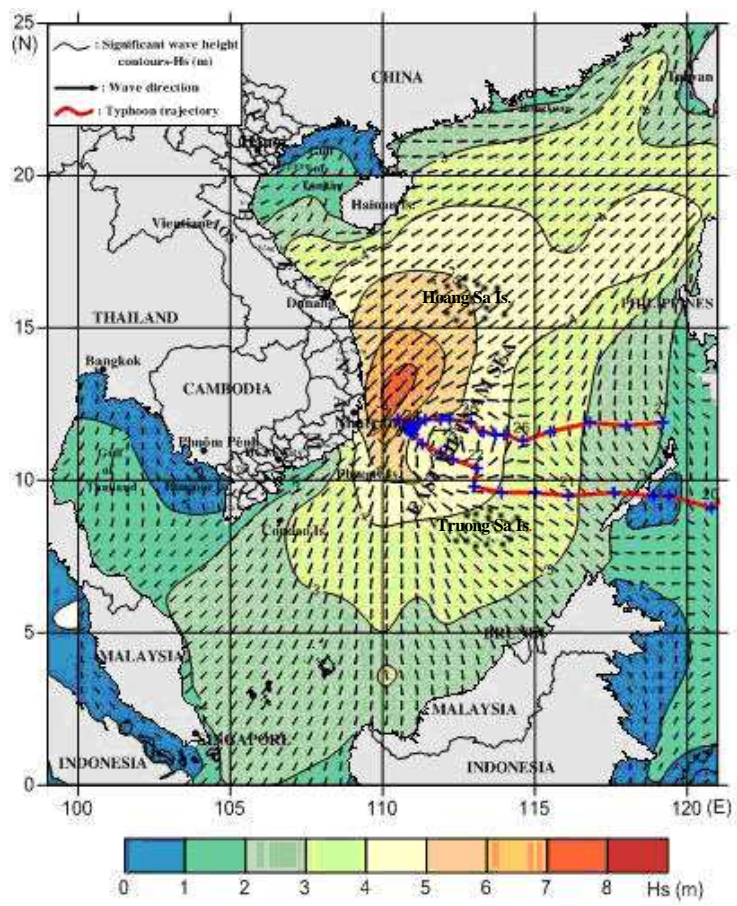

Fig. 6. Wave height pattern induced by typhoon Hagibis (at 06h 23/11/2007)

Typhoon Hagibis occurring in the EVS from $18 / 11$ to $27 / 11 / 2007$ induced maximum wave height in the offshore region of Nhatrang coast (at location: $12.125^{\circ} \mathrm{N}, 109.375^{\circ} \mathrm{E}$ ). Track of Hagibis is shown in fig. 5, 6. At $18 \mathrm{~h}$ $22 / 11 / 2007$ maximum wind velocity was $23.6 \mathrm{~m} / \mathrm{s}$, maximum wave height was $7.3 \mathrm{~m}$, wave period was $10.8 \mathrm{~s}$. In offshore region of Nhatrang coast maximum wave height was $5.6 \mathrm{~m}$, wave period was $11.1 \mathrm{~s}$. At $6 \mathrm{~h}$ 23/11/2007 Hagibis moved closer to Nhatrang coast and wind velocity reduced, but wave height and period are increased with $\mathrm{H}_{\mathrm{s}}=$ $6.3 \mathrm{~m}, \mathrm{~T}=11.1 \mathrm{~s}$. Wave height patterns induced by Hagibis at $18 \mathrm{~h} 22 / 11 / 2007$ and $6 \mathrm{~h}$ 23/11/2007 are shown in fig. 5, 6 respectively.

\section{Long term distribution features of wave characteristics in EVS}

Frequency distribution (\%) of $\mathrm{H}_{\mathrm{s}}>$ $1.0 \mathrm{~m}$ during 1/7/1987 - 31/12/2011 greater than $50 \%$ occurred in northeast, central region of EVS and central Vietnamese coast. The gulf of Thailand and Tonkin have frequency $<20 \%$ (fig. 7 ).

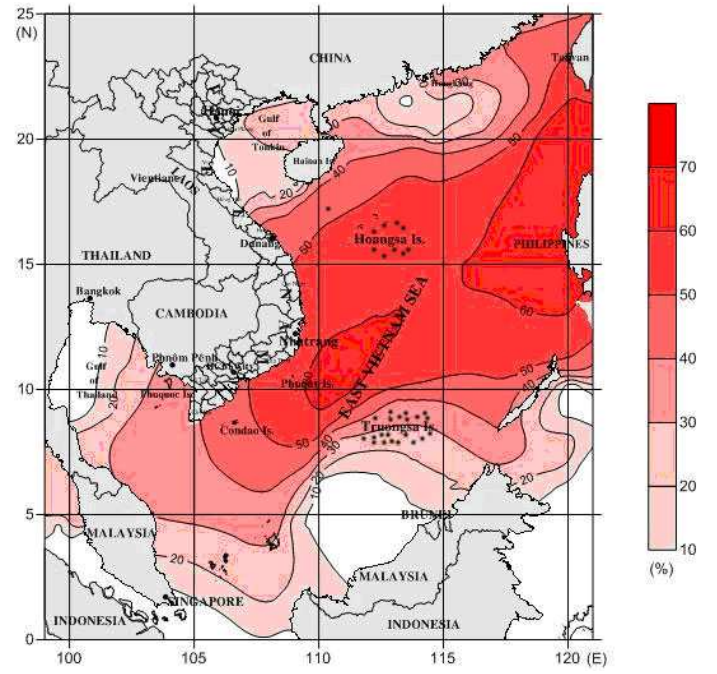

Fig. 7. Frequency distribution (\%) of occurrence in case of $\mathrm{H}_{\mathrm{s}}>1.0 \mathrm{~m}$ from 1/7/1987 to $31 / 12 / 2011$
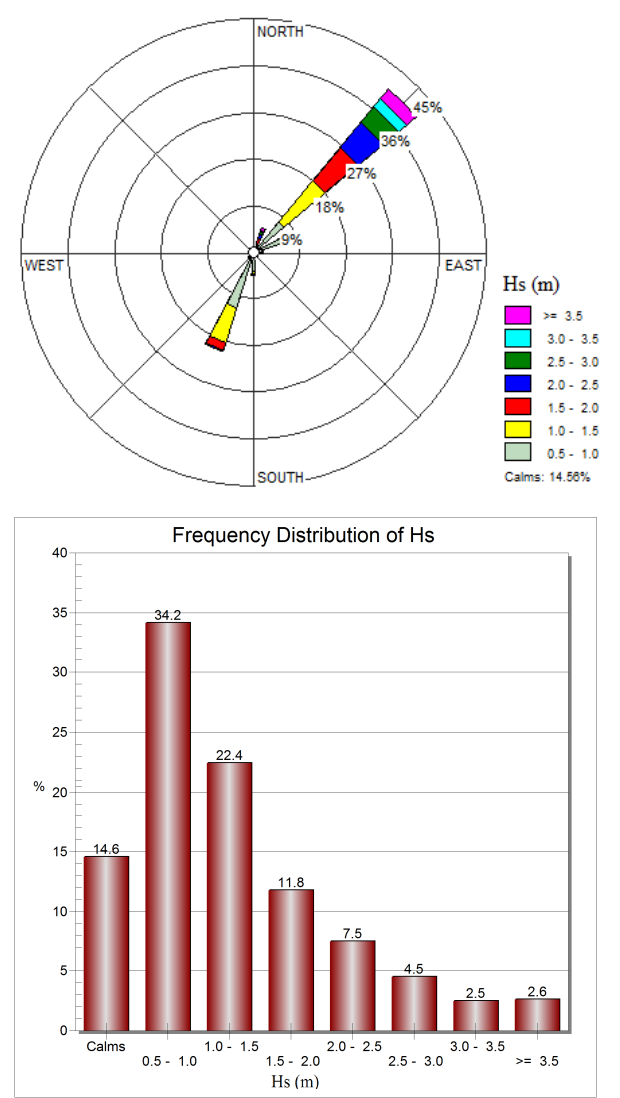

Fig. 8. Wave rose diagram and frequency distribution of occurrence of wave height off Nhatrang coast during 1/7/1987 - 31/12/2011 
Offshore region of Nhatrang coast is a region of narrow continent the depth contour of $200 \mathrm{~m}$ is close to the coastline. Therefore, this coast is most affected by wave action especially during NE monsoon period. Statistic of computed wave characteristics data for offshore region of Nhatrang coast (at point: $12.125^{\circ} \mathrm{N}$, $109.375^{0} \mathrm{E}$ ) from $1 / 7 / 1987$ to $31 / 12 / 2011$ shows that wave regime off Nhatrang coast has two main directions NE with $40.82 \%$ of occurrence, SSW with $20.15 \%$ of occurrence. $\mathrm{H}_{\mathrm{s}} \approx 0.5 \div$ $1.0 \mathrm{~m}$ occurred $34.16 \%, \mathrm{H}_{\mathrm{s}} \approx 1.0 \div 1.5 \mathrm{~m}$ occurred $22.43 \%$, and $\mathrm{H}_{\mathrm{s}}>1.5 \mathrm{~m}$ occurred $28.84 \%$ (fig. 8 ).

\section{CONCLUSIONS}

Frequency distribution (\%) of $\mathrm{H}_{\mathrm{s}}>1.0 \mathrm{~m}$ during 1/7/1987 - 31/12/2011 greater than 50\% occurred in northeast, central region of EVS and central Vietnamese coast. The gulf of Thailand and Tonkin have frequency of occurrence $<20 \%$;

Wave regime in the offshore region of Nhatrang coast from $1 / 7 / 1987$ to $31 / 12 / 2011$ indicates two main wave directions that are NE with $40.82 \%$ of occurrence, SSW with $20.15 \%$ of occurrence. $\mathrm{H}_{\mathrm{s}} \approx 0.5 \div 1.0 \mathrm{~m}$ occurred $34.16 \%, \mathrm{H}_{\mathrm{s}} \approx 1.0 \div 1.5 \mathrm{~m}$ occurred $22.43 \%$, and $\mathrm{H}_{\mathrm{s}}>1.5 \mathrm{~m}$ occurred $28.84 \%$. NE monsoon wave affected from October to April of the next year, SW monsoon wave affected from June to August. May and September are transitional periods.

With the assimilation of wind data of high resolution $\Delta \mathrm{X}=\Delta \mathrm{Y}=0.25^{0}$, the model can be used to simulate wave fields during typhoon activity in East Vietnam Sea

Acknowledgements: The authors gratefully acknowledge Dr. Gerhard Gayer, Department of Model System, Institute of Hydrophysics, GKSS, Germany for his kind help and encouragement throughout the preparation of WAM Cycle 4.5 model.

\section{REFERENCES}

1. WAMDI Group, 1988. The WAM model A third generation ocean wave prediction model, Journal of Physical Oceanography, 18(12): $1,775-1,810$.
2. Young, I. R., 1988. Parametric hurricane wave prediction model. Journal of Waterways Port Coastal and Ocean Engineering, 114(5): 637-652.

3. Londhe, S. N., Vijay Panchang, 2006. Oneday wave forecasts based on artificial neural networks. Journal of Atmospheric and Oceanic Technology, 23(11): 1,5931,603. Online publication date: 1-Nov2006.

4. Mandal, S., and Prabaharan, N., 2003. An overview of the numerical and neural network Accosts of ocean wave prediction, COPEDEC VI, 2003. Colombo, Sri Lanka.

5. Mau, L. D., Sanil Kumar, V., Nayak, G. N., Mandal, S., 2004. Estimation of wave characteristics during hurricane in the Hoian area, Central Vietnam. Proceeding of the Third Indian National Conference on Harbour and Ocean Engineering, 1, 105113.

6. Guenther, H., Hasselmann, S., Janssen, P. A. E. M., 1992. The WAM Model Cycle 4.0. User Manual. Technical Report No.4, Deutsches Klimarechenzentrum, Hamburg, Germany, 102 p.

7. Guenther, H., 2002. WAM Cycle 4.5. User Manual. Technical Report. Institute for Coastal Research GKSS Research Centre Geesthacht. Germany, 40 p.

8. Tolman, H. L., 1991. A third-generation model for wind waves on slowly varying, unsteady and inhomogeneous depths and currents. Journal of Physical Oceanography, 21, 782-797.

9. Chu, Peter C., Kuo-Feng Cheng, 2008. South China Sea wave characteristics during typhoon Muifa passage in winter 2004. Journal of Oceanography 64(1): 1-21. Online publication date: 1-Feb-2008.

10. Ali Mirzaei, Fredolin Tangang, Liew Juneng, Muzneena Ahmad Mustapha, Mohd Lokman Husain, Mohd Fadzil Akhir, 2013. Wave climate simulation for southern region of the South China Sea. Ocean Dynamics, 63(8): 961-977. Online publication date: 9-Jul-2013. 
11. Liangming Zhou, Zhanbin Li, Lin Mou, Aifang Wang, 2014. Numerical simulation of wave field in the South China Sea using WAVEWATCH III. Chinese Journal of Oceanology and Limnology, 1-9. Online publication date: 24-Jan-2014.
12. Lê Đình Mầu, 2006. Tính toán các đặc trưng sóng biển khơi bằng mô hình số trị WAM. Tạp chí Khoa học và Công nghệ biển. Hà Nội, Việt Nam, Tập 6 , Số 3 . Tr. 26-39.

\title{
TÍNH TOÁN CÁC ĐĂC TRƯNG SÓNG TRÊN BIỂN ĐÔNG BẰNG MÔ HİNH WAM
}

\author{
Lê Đình Mầu, Nguyễn Văn Tuân
}

Viện Hải dương học-Viện Hàn lâm Khoa học và Công nghệ Việt Nam

TÓM TÄT: WAM (WaveModeling) là mô hình tính sóng thế hệ thứ 3 được xây dụng và phát triển bởi tập thể các nhà khoa học nghiên cứu sóng trên thế giới (WAMDI Group), mồ hình mô tả sụ phát triển của phổ sóng hai chiều dưới tác động của gió, dòng chảy, địa hình đáy và tuoong tác phi tuyến sóng - sóng. Mô hình tính toán các đặc trung sóng biển sâu, biển nông bao hàm hiệu ứng khúc xạ sóng bởi nước nông và dòng chảy. Mô hình WAM phiên bản 4.5 (WAM cycle 4.5) đã được áp dụng với khu vục tính toán là toàn bộ Biển Đông tù $99^{\circ} \mathrm{E}$ đến $121^{\circ} \mathrm{E}$ và $0^{\circ} \mathrm{N}$ đến $25^{\circ} \mathrm{N}$ với kích thuoớc lưới tính là $\Delta X=\Delta Y=0,25^{\circ}$. Độ sâu Biển Đông lấy tù co sở dũ liệu 'ETOPO5' của Trung tâm dũ liệu Địa vật lý quốc gia Colorado, Hoa Kỳ với độ phân giải $5^{\prime}$ ( $\left.\approx 9 \mathrm{~km}\right)$. Số liệu gió $6 \mathrm{~h} / \mathrm{lần}$ lấy tù cơ sở dũ liệu NCEP/NCAR, Hoa Kỳ với độ phân giải $\Delta X=\Delta Y=0,25^{\circ}$. Kết quả tính toán cho thấy thời kỳ gió mùa Đông Bắc (NE Monsoon) trên toàn Biển Đông sóng có huoóng chủ đạo là Đông Bắc (NE) và có huoóng ngược lại trong thời kỳ gió mùa Tây Nam (SW monsoon). Khu vưc trung tâm và Đông Bắc của Biển Đông có độ cao sóng lớn nhất. Thống kê kết quả tính toán các đặc trung sóng tù 1987 đến 2011 cho thấy chế độ sóng ngoài khơi Nha Trang có hai huớng chính là NE chiếm 40,82\%, SSW chiếm 20,15\%. Sóng hướng NE tác động tì̀ tháng 10 đến tháng 4 năm sau, sóng SSW tác động tù tháng 6 đến tháng 8, tháng 5 và 9 là các thời kỳ chuyển tiếp. Tập dũ liệu gió với độ phân giải $\Delta X=\Delta Y=0,25^{0}$ cho phép mô phỏng truờng sóng trong bão trên Biển Đông.

Tù khoá: WAM cycle 4.5, Biển Đông, truờng sóng, bão, gió mùa. 